\title{
Species of Harpacticoida (Crustacea, Copepoda) from the phytal of Porto de Galinhas coral reefs, northeastern Brazil
}

\author{
Visnu Cunha Sarmento* and Paulo Jorge Parreira Santos

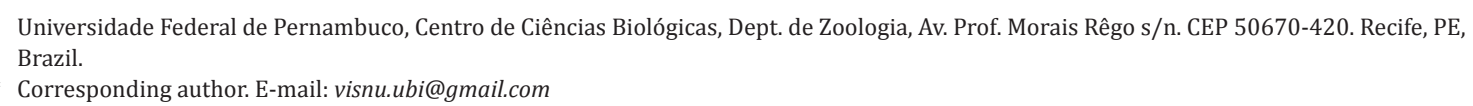

ABSTRACT: The coral reefs of Porto de Galinhas Beach (Pernambuco, Brazil, Northeast region) are among the most important tourist destinations in the country. However, this ecosystem is being increasingly threatened by impacts related to tourism. A first list of the Harpacticoida species found in the phytal of these reefs is provided here. The total of 1501 individuals analyzed included 42 species belonging to 13 families and 32 genera. The dominant species were Parastenhelia spinosa, Amphiascoides sp., Robertsonia knoxi, Ameira parvula, Paralaophonte congenera congenera and Amphiascopsis cinctus. First records for the Brazilian coast include the subspecies Nitocra affinis californica and nine species: Nannomesochra arupinensis, Cletodes aff. pseudodissimilisoris, Esola lobata, Paralaophonte congenera (sensu Yeatman 1962), Sarsamphiascus parvus (sensu Rouch 1962), Rhyncholagena littoralis, Stenhelia gibba, Alteutha roeae and Xouthous purpurocinctus. The high diversity and the isocommunity hypothesis are discussed.

\section{INTRODUCTION}

The Brazilian coral reefs form unique structures that differ significantly from other well-known coral reefs in the world, in their low-diversity coral fauna which is rich in endemic species; the presence of a relict fauna from the Tertiary, which forms unusual mushroom-shaped coral pinnacles; the important role of encrusting coralline algae in the construction of the reef structure; and the nearshore bank reefs that may be surrounded by and even filled with muddy siliciclastic sediments. These reefs are among the most conspicuous marine ecosystems of tropical Brazil, and include the southernmost coral-reef communities in the Atlantic Ocean (Maida and Ferreira 1997; Leão and Dominguez 2000).

The coral reefs of Porto de Galinhas Beach in the state of Pernambuco, northeast Brazil are one of the mostimportant tourist destinations in the country. These formations have a total area of $0.42 \mathrm{~km}^{2}$ and are located very near the coast. Due to the ease of access, large numbers of tourists are taken daily by rafts and are allowed to disembark and walk across reef formations during tides below $0.4 \mathrm{~m}$ when the reef is exposed (Alcantara et al. 2004). The same reef also contains areas that have been permanently conserved since 2004 (between 2004 and 2009, 70\% of the total reef area was protected). These areas are marked by buoys and ropes, and tourists are forbidden to enter. Of the reef areas that are both exposed during low tides and easy to access, this is the only protected area along the coast of Pernambuco.

On the reef flat, the hard substrate is dominated by zoanthids and thick turf-forming macroalgae (Maida and Ferreira 1997). Macroalgae are among the major contributors to reef primary production, and provide shelter to an extremely abundant meiofauna assemblage (Gibbons and Griffiths 1986).

Harpacticoida is one of nine orders of the subclass
Copepoda. Harpacticoids are small crustaceans (ranging from 0.2 to $2.5 \mathrm{~mm}$ in length), and among Copepoda, they are the most quantitatively important order in marine benthic ecosystems. This order comprises nearly 6,000 species in 645 genera and 59 families (Wells 2007; Giere 2009; Ahyong et al. 2011). However, data from well-studied shallow coastal areas (Veit-Koehler et al. 2010) can include proportions of unidentified species as high as 54\%. Moreover, deep-sea expeditions have reported a mean of $97 \%$ unknown species (George and Schminke 2002; Seifried 2004). Extrapolating from these proportions indicates that more than 21,000 additional unrecorded species exist.

In phytal environments, Harpacticoida is regularly the dominant meiofauna taxon (Hicks 1977; Coull et al. 1983; Hall and Bell 1993) and shows high diversity (Hicks 1985; Sarmento et al. 2012). Harpacticoids have high fatty-acid contents, derived from their preferred diatom food, and play a decisive nutritional role for small fish, carnivorous crustaceans (shrimp and their larvae), and polychaetes (Coull 1999; Giere 2009). Thus, these metazoans are a key component of the benthic ecosystem, contributing significantly to energy transfer to higher trophic levels (Coull 1988; Danovaro et al. 2007).

This report lists the species of Harpacticoida inhabiting the phytal environment of reef formations at Porto de Galinhas Beach in Pernambuco. This information provides a basis to improve knowledge of the local biodiversity, which is increasingly threatened by tourism.

\section{Materials AND Methods}

Samples were collected in February, October, November and December 2009 on the reefs of Porto de Galinhas Beach, located at $08^{\circ} 30^{\prime} 26^{\prime \prime}$ to $08^{\circ} 30^{\prime} 39^{\prime \prime} \mathrm{S}$, and $34^{\circ} 59^{\prime} 52^{\prime \prime}$ to $34^{\circ} 59^{\prime} 55^{\prime \prime} \mathrm{W}$ (Figure 1). In total, 57 sampling sites were randomly selected across the reef flat. Samples were taken 
using a corer to delimit a $10 \mathrm{~cm}^{2}$ area. The turfs were collected by cutting the algal turf down to the reef surface using a metal scraper, to ensure that all turf and underlying sediment were removed. Meiofauna samples were preserved in $4 \%$ formalin in seawater in the field. In the laboratory, meiofauna was extracted from turfs by manual elutriation with filtered water, through geological sieves with mesh sizes of 0.5 and $0.063 \mathrm{~mm}$. Under a Leica EZ4 stereomicroscope, the first 25 individuals of harpacticoid copepods were selected from each replicate and placed in Eppendorf tubes with $70 \%$ ethanol. The harpacticoids were identified under an optical microscope (Leica DM 2500) following the taxonomic keys of Lang (1948; 1965), Huys et al. (1996) and Wells (2007), as well as original species descriptions. Specimens have been deposited in the Coleção de Carcinologia of the Museu de Oceanografia Petrônio Alves Coelho at the Universidade Federal de Pernambuco (MOUFPE). The Shannon-Wiener ( $\mathrm{H}$ ', using $\log _{2}$ ), Pielou's evenness (J') and Species Richness indices were calculated using the software Primer ${ }^{\circledR}$ V.6 (Plymouth Routines in Multivariate Ecological Researches).

\section{RESULTS AND DisCuSSION}

A total of 1501 individuals of harpacticoid copepods were analyzed, and 42 species, belonging to 13 families and 32 genera, were recorded for the phytal of Porto de Galinhas reefs (Table 1). This checklist adopts the nomenclatural modifications proposed by Huys (2009). Species of the families Ectinosomatidae, Harpacticidae, Normanellidae and Tisbidae were not identified, because of a small number of individuals found (e.g., Normanella and Tisbe) or due to the urgent need for revisions of certain genera (e.g., Ectinosoma and Harpacticus).

The dominant families in the study area were Miraciidae (with $38.13 \%$ of total individuals), Parastenheliidae (15.55\%) and Laophontidae (10\%). Miraciidae had the highest number of species (13), followed by Laophontidae (9), Ameiridae (4) and Canthocamptidae (3). The other families had only one or two species.

The dominant species were Parastenhelia spinosa (15.55\%), Amphiascoides sp. (8.6\%), Robertsonia knoxi (7.76\%), Ameira parvula (6.52\%), Paralaophonte

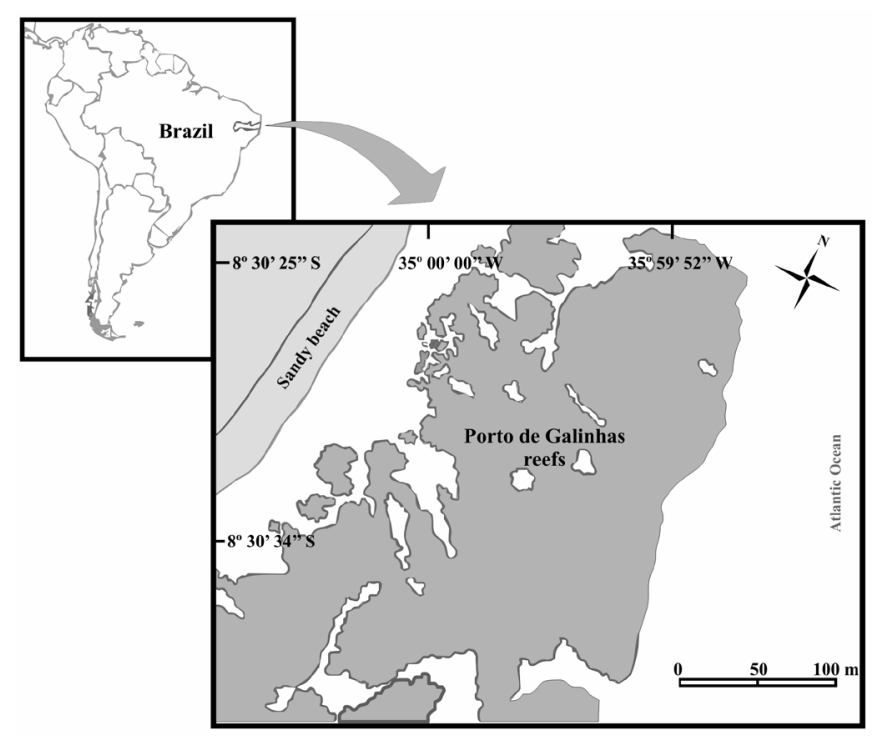

FIGURE 1. Study area on the reef formation located at Porto de Galinhas Beach, state of Pernambuco, northeastern Brazil. congenera congenera (5.44\%) and Amphiascopsis cinctus (5.13\%), which together accounted for about $49 \%$ of the total of individuals.

A review of the literature about Brazilian harpacticoids (Reid 1998; Wandeness et al. 1998; Sarmento and Santos 2012; Sarmento et al. 2012) shows that the subspecies Nitocra affinis californica and the following nine species are recorded for the first time along the Brazilian coast: Nannomesochra arupinensis, Cletodes aff. pseudodissimilisoris, Esola lobata, Paralaophonte congenera (sensu Yeatman 1962), Sarsamphiascus parvus (sensu Rouch 1962), Rhyncholagena littoralis, Stenhelia gibba, Alteutha roeae and Xouthous purpurocinctus. Members of the genera Nitocra and Stenhelia are recorded for the first time for the phytal of Porto de Galinhas reef.

The assemblage of Copepoda Harpacticoida found in the phytal of Porto de Galinhas had high levels of species richness (total 42 species), evenness (overall $\mathrm{J}^{\prime}=0.81$ ) and diversity (overall $\mathrm{H}^{\prime}\left(\log _{2}\right)=4.52$ bits). This level of diversity is higher than most diversity values reported for other phytal environments, as well as most of those for sediments in other coastal environments (Sarmento et al. 2012). However, the diversity calculated for the phytal of Porto de Galinhas was very similar to the values reported by Sarmento et al. (2012) in the phytal of Arraial do Cabo rocky shores in Rio de Janeiro, Brazil.

Areas covered by different species of algae, which are associated with large amounts of filamentous epiphytes, have much greater spatial heterogeneity compared to more homogeneous or monospecific areas (Hicks 1985). Environmental complexity implies that the different microhabitats will favor the establishment of animals with different habits and/or morphological adaptations. Consequently, this allows the coexistence of different species, foraging different niches in the phytal and decreasing competitive interactions, with the consequent establishment of a diverse harpacticoid fauna (Hicks 1977; Arroyo et al. 2006).

In the present study, the turfs covering Porto de Galinhas reefs were formed mainly by two species of algae: Chondrophycus papillosus (Agardh) Garbary and Harper and Gelidiella acerosa (Forsskål) Feldmann and Hamel (Figure 2). These algae have a thallus with several tufted, entangled, cylindrical, stiff to cartilaginous branches. It is apparent that these algae together with epiphytes and the attached sediment provide a suitable habitat for the highly diverse harpacticoid assemblage found in Porto de Galinhas.

In a previous study, Sarmento et al. (2012) discussed the concept of isocommunities in the phytal environment. This concept suggests that similar substrates, although geographically separated, are inhabited or colonized by the same set of dominant genera, although the species composition may vary between sites (Por 1964). Arraial do Cabo and Porto de Galinhas are located along the same coast, but certain significant differences between these sites and studies can be noted. In addition to their separation by nearly $2,300 \mathrm{~km}$, the algal composition is very different. Furthermore, in Arraial do Cabo, the sea water has a mean temperature of $20^{\circ} \mathrm{C}$ and the samples were taken in the subtidal on rocky shores. On the other hand, in Porto de Galinhas the mean water temperature 
is around $27^{\circ} \mathrm{C}$ and samples were taken in the intertidal of coral reefs. Despite these differences, in the phytal of Porto de Galinhas about $65 \%$ of the recorded genera were the same as those found by Sarmento et al. (2012) in the phytal of Arraial do Cabo. Thus, this similarity in genus composition reinforces the hypothesis of geographical parallelism or isocommunities for phytal environments.

Differently from other crustacean inventories, in the present study, many (35.7\%) of the animals collected belong to undescribed species. However, this is a very common result for Harpacticoida. The state of knowledge of the taxonomy of these animals varies enormously among geographic regions. The harpacticoid fauna of certain regions (such as the North Sea in Europe) has been well studied and described since the $19^{\text {th }}$ century (for literature see Wells 2007 and Huys 2009). On the other hand, despite the great extent of the Brazilian coast, taxonomic studies of Harpacticoida are few and have resumed only recently (e.g., Kihara and Rocha 2007; Vasconcelos et al. 2008; 2009; Wandeness et al. 2009), after some earlier descriptions during the 1950s, mainly by Hans Jakobi (some of these species are now considered species inquirendis).

The harpacticoid copepod fauna in the phytal of Porto de Galinhas is highly diverse. A recent study has demonstrated the importance of these organisms as potential bioindicators of human disturbance in sensitive areas such as coral reefs (Sarmento and Santos 2012). Therefore, studies on the biodiversity of these animals in coral reefs and other environments need to be encouraged, especially in regions where taxonomic knowledge is inadequate, such as the Brazilian coast.

TABLE 1. List of Harpacticoida species found in the phytal environment of Porto de Galinhas reef (Pernambuco, northeastern Brazil).

\begin{tabular}{|c|c|c|}
\hline \multicolumn{2}{|c|}{ Order Harpacticoida Sars 1903} & \multirow{2}{*}{ Voucher } \\
\hline Family & Species & \\
\hline \multirow{3}{*}{ Family Ameiridae Boeck 1865} & Ameira parvula (Claus, 1866) & MOUFPE14961 \\
\hline & Psyllocamptus (Psyllocamptus) sp.1 & MOUFPE14963 \\
\hline & Psyllocamptus (Psyllocamptus) sp.2 & MOUFPE14964 \\
\hline \multirow{3}{*}{ Family Canthocamptidae Brady 1880} & Mesochra pygmaea (Claus, 1863) & MOUFPE14965 \\
\hline & Mesochra sp. & MOUFPE14966 \\
\hline & Nannomesochra arupinensis (Brian, 1925) & MOUFPE14967 \\
\hline \multirow{2}{*}{ Family Cletodidae T. Scott 1905} & Cletodes aff. pseudodissimilisoris Gómez, 2000 & MOUFPE14968 \\
\hline & Cletodes sp. & MOUFPE14969 \\
\hline \multirow{2}{*}{ Family Dactylopusiidae Lang 1936} & Dactylopusia tisboides (Claus, 1863) & MOUFPE14970 \\
\hline & Paradactylopodia brevicornis (Claus, 1866) & MOUFPE14971 \\
\hline \multirow{9}{*}{ Family Laophontidae T. Scott 1905} & Esola lobata Huys and Lee, 2000 & MOUFPE14972 \\
\hline & Esola vervoorti Huys and Lee, 2000 & MOUFPE14973 \\
\hline & Heterolaophonte campbelliensis (Lang, 1934) & MOUFPE14974 \\
\hline & Laophonte cornuta Philippi, 1840 & MOUFPE14975 \\
\hline & Laophonte parvula Sars, 1908 & MOUFPE14976 \\
\hline & Loureirophonte sp. & MOUFPE14977 \\
\hline & Paralaophonte brevirostris (Claus, 1863) & MOUFPE14978 \\
\hline & Paralaophonte congenera congenera (Sars, 1908) & MOUFPE14979 \\
\hline & Paralaophonte congenera (Sars, 1908) [sensu Yeatman 1962] & MOUFPE14980 \\
\hline Family Longipediidae Boeck 1865 & Longipedia sp. & MOUFPE14981 \\
\hline Family Louriniidae Monard 1927 & Lourinia armata (Claus, 1866) & MOUFPE14982 \\
\hline \multirow{2}{*}{ Family Metidae Boeck 1873} & Laubieria sp. & MOUFPE14983 \\
\hline & Metis holothuriae (Edwards, 1891) [sensu Vervoort 1964] & MOUFPE14984 \\
\hline \multirow{13}{*}{ Family Miraciidae Dana 1846} & Amonardia sp. & MOUFPE14985 \\
\hline & Amphiascoides sp. & MOUFPE14986 \\
\hline & Amphiascopsis cinctus (Claus, 1866) & MOUFPE14987 \\
\hline & Diosaccus sp. & MOUFPE14989 \\
\hline & Melima sp.1 & MOUFPE14990 \\
\hline & Melima sp.2 & MOUFPE14991 \\
\hline & Paramphiascella robinsoni (A. Scott, 1902) [sensu Gurney 1927] & MOUFPE14992 \\
\hline & Rhyncholagena littoralis Por, 1967 & MOUFPE14993 \\
\hline & Robertsonia knoxi (Thompson and A. Scott, 1903) & MOUFPE14994 \\
\hline & Robertsonia mourei Nogueira, 1961 & MOUFPE14995 \\
\hline & Sarsamphiascus parvus Sars, 1906 [sensu Rouch 1962] & MOUFPE14988 \\
\hline & Stenhelia gibba Boeck, 1865 & MOUFPE14996 \\
\hline & Typhlamphiascus sp. & MOUFPE14997 \\
\hline \multirow{2}{*}{ Family Orthopsyllidae Huys 1990} & Orthopsyllus sp.1 & MOUFPE14998 \\
\hline & Orthopsyllus sp.2 & MOUFPE14999 \\
\hline Family Parastenheliidae Lang 1936 & Parastenhelia spinosa (Fischer, 1860) & MOUFPE15000 \\
\hline Family Peltidiidae Claus 1860 & Alteutha roeae Hicks, 1982 & MOUFPE15001 \\
\hline Family Pseudotachidiidae Lang 1936 & Xouthous purpurocinctus (Norman and T. Scott, 1905) & MOUFPE15002 \\
\hline
\end{tabular}




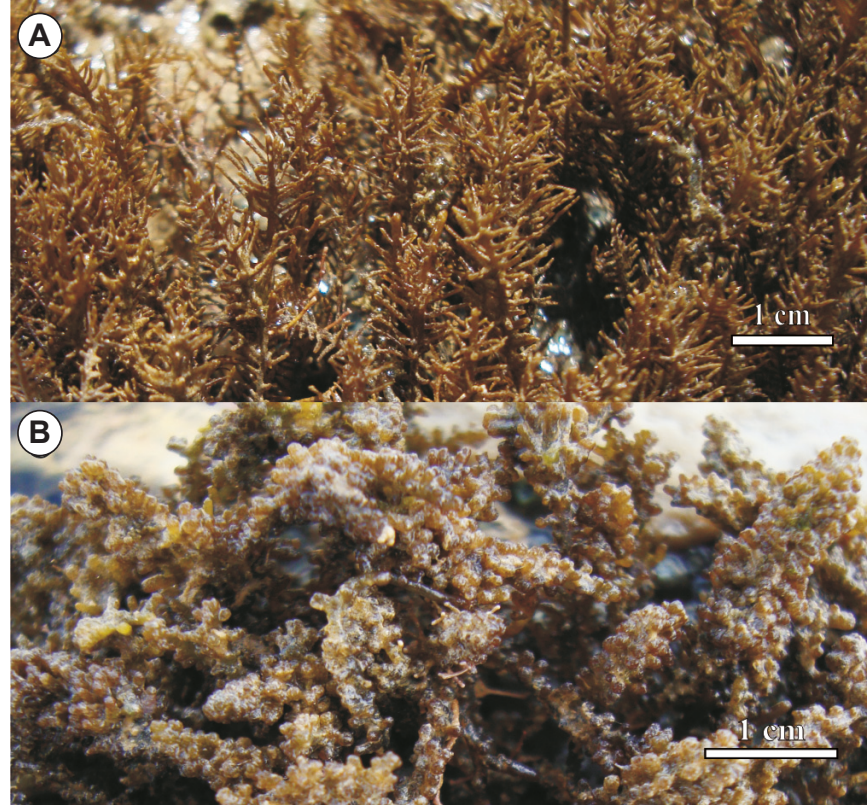

FiguRE 2. Two main species of algae covering the reefs at Porto de Galinhas in northeastern Brazil. a) Gelidiella acerosa and b) Chondrophycus papillosus.

ACKNOWLEDGMENTS: V.C. Sarmento acknowledges a MSc scholarship, and P.J.P. Santos acknowledges a research fellowship (305609/2004-1) from CNPq. Thanks are due to Dr. Janet W. Reid for English language revision, Aliny F.S. Barreto for help with field sampling and harpacticoid sorting, and to Dr. Adilma M. Cocentino for the algae identifications. Thanks are also due to two anonymous reviewers for providing comments that improved the manuscript.

\section{LITERATURE CITED}

Ahyong, S.T., J.K. Lowry, M. Alonso, R.N. Bamber, G.A. Boxshall, P. Castro, S. Gerken, G.S. Karaman, J.W. Goy, D.S. Jones, K. Meland, D.C. Rogers, D.C. and J. Svavarsson. 2011. Subphylum Crustacea Brünnich, 1772. In Z.-Q. Zhang (ed.). Animal Biodiversity: An Outline of Higher-level Classification and Survey of Taxonomic Richness. Zootaxa 3148: 165-191.

Alcantara, R., B.P. Ferreira and P. Travassos. 2004. A pesca artesanal e o turismo em Porto de Galinhas, Pernambuco. Boletim Técnico Científico CEPENE 12 (1): 195-207.

Arroyo, L.N., M. Maldonado and K. Walters. 2006. Within- and betweenplant distribution of harpacticoid copepods in a North Atlantic bed of Laminaria ochroleuca. Journal of the Marine Biological Association of the United Kingdom 86: 309-316.

Coull, B.C. 1988. Ecology of the marine meiofauna; p. 18-38 In R.P. Higgins and H. Thiel (eds.). Introduction to the Study of Meiofauna. Washington DC: Smithsonian Institution Press.

Coull, B.C. 1999. Role of meiofauna in estuarine soft-bottom habitats. Australian Journal of Ecology 24: 327-343.

Coull, B.C., E.L. Creed, R.A. Eskin, P.A. Montagna, M.A. Palmer and J.B.J. Wells. 1983. Phytal meiofauna from the rocky intertidal at Murrells Inlet, South Carolina. Transactions of the American Microscopical Society 102: 380-389.

Danovaro, R., M. Scopa, C. Gambi and S. Fraschetti. 2007. Trophic importance of subtidal metazoan meiofauna: evidence from in situ exclusion experiments on soft and rocky substrates. Marine Biology 152: 339-350

George, K.H. and H.K. Schminke. 2002. Harpacticoida (Crustacea, Copepoda) of the Great Meteor Seamount, with first conclusions as to the origin of the plateau fauna. Marine Biology 144: 887-895.

Gibbons, M.J. and C.L. Griffiths. 1986. A comparison of macrofaunal and meiofaunal distribution and standing stock across a rocky shore, with an estimate of their productivities. Marine Biology 93:181-188.

Giere, 0. 2009. Meiobenthology: The Microscopic Motile Fauna of Aquatic Sediments. $2^{\text {nd }}$ ed. Berlin: Springer-Verlag.

Gurney, R. 1927. Zoological results of the Cambridge Expedition to the Suez Canal, 1924. XXXIII. Report on the Crustacea: Copepoda (littoral and semi-parasitic). Transactions of the Zoological Society of London 22: 451-577.

Hall, M.O. and S.S. Bell. 1993. Meiofauna on the seagrass Thalassia testudinum: population characteristics of harpacticoid copepods and associations with algal epiphytes. Marine Biology 116: 137-146.

Hicks, G.R.F. 1977. Species associations and seasonal population densities of marine phytal harpacticoid copepods from Cook Strait. New Zealand Journal of Marine and Freshwater Research 11 (4): 621-643.

Hicks, G.R.F. 1985. Meiofauna associated with rocky shore algae; p. 36-56 In P.G. Moore and R. Seed (eds.). The Ecology of Rocky Coasts. New York: Columbia University Press.

Huys, R. 2009. Unresolved cases of type fixation, synonymy and homonymy in harpacticoid copepod nomenclature (Crustacea: Copepoda). Zootaxa 2183: 1-99.

Huys, R., J.M. Gee, C.G. Moore and R. Hamond. 1996. Marine and Brackish Water Harpacticoid Copepods. Part 1: keys and notes for identification of the species; p. 1-352 In R.S.K. Barnes and J.H. Crothers (eds.). Synopses of the British Fauna (New Series) no. 51, Shrewsbury: Field Studies Council.

Kihara, T.C. and C.E.F. Rocha. 2007. Microarthridion corbisierae sp. nov. (Harpacticoida, Tachidiidae), um novo copépode da meiofauna do litoral norte do estado de São Paulo, Brasil. Revista Brasileira de Zoologia 24 (4): 907-918.

Lang, K. 1948. Monographie der Harpacticiden: I: 1-896; II: 897-1682. Lund: Håkan Ohlsson Booksellers. Stockholm, Nordiska Bökhandeln. $1682 \mathrm{p}$.

Lang, K. 1965. Copepoda Harpacticoidea from the Californian Pacific Coast. Kungliga Svenska Vetenskapsakademiens Handlingar. Fjärde Serien, 10(2): 1-560 p.

Leão, Z.M.A.N. and J.M.L. Dominguez. 2000. Tropical coast of Brazil Marine Pollution Bulletin 41 (1-6): 112-122.

Maida, M. and B.P. Ferreira. 1997. Coral reefs of Brazil: an overview; $p$ 263-274 In H.A. Lessios and I.G. Macintyre (eds.). Proceedings of the $8^{\text {th }}$ International Coral Reef Symposium, Vol. 1. Smithsonian Tropical Research Institute, Panama.

Por, F.D. 1964. A study of the Levantine and Pontic Harpacticoida (Crustacea, Copepoda). Zoologische Verhandelingen 64: 1-128.

Reid, J.W. 1998. Maxillopoda - Copepoda Harpacticoida; p. 75-127 In P.S. Young (ed.). Catalogue of Crustacea of Brazil. Série Livros 6. Rio de Janeiro. Museu Nacional.

Rouch, R. 1962. Harpacticoïdes (Crustacés Copépodes) d'Amérique du Sud; p. 237-280 In C. Delamare Deboutteville and E. Rapoport (Eds.) Biologie de l'Amérique Australe, CNRS, Paris, Vol. 1.

Sarmento, V.C., L.M. Lage and P.J.P. Santos. 2012. Copepoda Harpacticoida community of a rocky shore under the influence of upwelling (Arraial do Cabo, southeastern Brazil). Journal of the Marine Biological Association of the United Kingdom 92(5): 1117-1126.

Sarmento, V.C. and P.J.P. Santos. 2012. Trampling on coral reefs: tourism effects on harpacticoid copepods. Coral Reefs 31: 135-146.

Seifried, S. 2004. The importance of a phylogenetic system for the study of deep-sea harpacticoid diversity. Zoological Studies 43(2): 435-445.

Vasconcelos, D.M., K.H. George and P.J.P. Santos. 2008. First record of the genus Pseudomesochra T. Scott (Harpacticoida: Pseudotachidiidae) in the South Atlantic with description of a deep-sea species: Pseudomesochra longiseta sp. nov. Zootaxa 1866: 337-348.

Vasconcelos, D.M., G. Veit-Köhler, J. Drewes and P.J.P. Santos. 2009. First record of the genus Kliopsyllus Kunz, 1962 (Copepoda Harpacticoida, Paramesochridae) from Northeastern Brazil with description of the deep-sea species Kliopsyllus minor sp. nov. Zootaxa 2096: 327-337.

Veit-Köhler, G., M. De Troch, M. Grego, T.N. Bezerra,W. Bonne, G. De Smet, C. Folkers, K.H. George, C. Guotong, R. Herman, R. Huys, N. Lampadariou, J. Laudien, P. Martínez Arbizu, A. Rose, M. Schratzberger, S. Seifried, P. Somerfield, J. Vanaverbeke, E. Vanden Berghe, M. Vincx, B. Vriser and L. Vandepitte. 2010. Large-scale diversity and biogeography of benthic copepods in European waters. Marine Biology 157:18191835.

Vervoort, W. 1964. Free-living Copepoda from Ifaluk Atoll in the Caroline Islands with notes on related species. Bulletin of the United States National Museum 236: 1-431.

Wandeness, A.P., A.M. Esteves, C.S.R. Nogueira and V. Fonsêca-Genevois 1998. Copepoda Harpacticoida meiobentônicos da Coroa do Avião, Pernambuco. Trabalhos Oceanográficos da Universidade Federal de Pernambuco 26 (2): 99-104.

Wandeness, A.P., K.H. George and P.J.P. Santos. 2009. First record of the taxon Echinopsyllus (Copepoda, Harpacticoida, Ancorabolidae) from the deep sea of Campos Basin, Brazil, with the description of three new species and their contribution to phylogenetic analysis. Zoological Journal of the Linnean Society 156: 52-78.

Wells, J.B.J. 2007. An annotated checklist and keys to the species of Copepoda Harpacticoida (Crustacea). Zootaxa 1568: 1-872.

Yeatman, H.C. 1962. The problem of dispersal of marine littoral copepods in the Atlantic Ocean, including some redescriptions of species. Crustaceana 4: 253-272.

RECEIVED: May 2012

ACCEPTED: August 2012

PuBLISHED ONLINE: September 2012

EDITORIAL RESPONSIBILITY: Luis Ernesto Arruda Bezerra 